\title{
切刃チッピング現象の確率的表示
}

\author{
非川招战* 安木国晴**
}

\section{A PROBABILISTIC APPROACH TO CUTTING EDGE CHIPPING}

\section{By Naoya Ikawa and Kuniharu Yasugi}

\begin{abstract}
A probabilistic method is proposed for the prediction of cutting edge chipping produced by purely mechanical load. It shows the possible sites for the chipping to take place at a certain level of probability. The contour map for the probability of chipping can be obtained by comparing the distribution of the principal stresses in a cutting edge with the statistical fracture criteria for sintered carbide as a tool material. For a particular set of cutting conditions, the aspect of the chipping observed in the orthogonal cutting test at low speed can be predicted fairly well by the contour map for the probability. It is shown quantitatively by these theoretical and experimental analyses that the extent of the chipping increases with increase in the rake and the clearance angles and is affected significantly by the condition of the tool engagement with the workpiece.
\end{abstract}

\section{1. 緒言}

切削工具切刃のチッピング現象の解明とその制御は切 削加工におけるいわば古典的な問題であるが，それが内 包する要因の複雑さの故に, 従来よ゙ちらかといえば現象 論的取扱いにたよらざるを得なかった。しかし最近のよ うに信頼性の高い工具が要求されるようになると，その 製造法や使用法についての指導原理を確立するためには, 工具損耗を支配する基本現象の解明が，た之えそれが実 用的観点からやや離れた上しても，従来にあまして重要 になってくる。

工具切刃のチッピングあるいは欠損***はさまざまな 悓象の複合作用の結果生じるもの上考えられるが, 直感 的には工具刃先内に発生する応力上，それによって工具 材料に破壊が起るから゙うかよいう刃先強度上の関係がき め手になる上考えられる。てのような観点から，てれま でに筆者らを含めて，工具刃先内の応力についていくつ かの解析がなされてきた1价。一方，工具材料，特に超 硬合金の破壊については，乙れまで材料学的立場からの 研究はかなり多くみられてきだとはいえ，そのクライテ リアについてはほ上んど情報が得られていなかったので はあるが, 比較的最近になって筆者らによって, 刃先の 破壊を想定した強度試駖にもとづき, 統計的性質, 寸法

* 正会員 大阪大学工学部（吹田市山田上）

**正会員大阪大学工学部（現・光洋精工；柏原市国分 東条町 $24-1$ )

***とこでは厳密な区別をせず，切込程度以下の寸法の刃先 破壊をチッピング，それを越える大きなあのを欠損とよ ふととにする。
効果及び動的効果をふくめたものが提鼠された ${ }^{81}$ 。

本研究は，筆者らに上る工具內先内応力分布の解析結 果 $^{4), 51}$ 上, 超硬合金の破壊に関する統計的クライテリア ${ }^{81}$ を対比することにより，機械的負荷による工具㹝先の破 壊を、現象発生の等確率線図上いう形で表現しよう上試 みるものであり，基本的には，工具の信頼性の数量的表 示につながるあのである。本報では、チッピング現象の 確率的表示の手順をのへ，その手法老二次元切削におけ るチッピング現象に適用し，実験による観察結果上対比 させながら工具形状や切削条件の影響存考察しよう上す る。

\section{2. チッピングの発生確率}

切內内部の応力分布が推定できると，ある応力状態に さらされている点または微小領域での破壊の叮能性は, その状態上工具材料の应力からみた破壊のクライテリア 上の対比によって知るこ上ができる。この上きクライテ リアが統計的なものであるならば，破壊の発生確率上い う形で知るこ上ができる。

切刃内部の応力分布は，切削力をむとにして，電算機 を用いる数值計算によって，た上えば図14０ように求 めるこ上ができる。また二次元応力下での超硬合金の破 壊のクライテリアについては，鋳鉄のように脆い金属に 対してFisherによって提案された決定論的な条件 ${ }^{9 !}$ と, 統計的なWeibull の破壊理論 ${ }^{10)}$ 組合せることにより図 2 亿示すむのが得られている8 。その意味は次のようである。 材料内のある一点（または微小領域）における主応力 を $\sigma_{1}, \sigma_{2}\left(\sigma_{1}>\sigma_{2}\right)$ とし, その点の破壊の確率をきめる量 


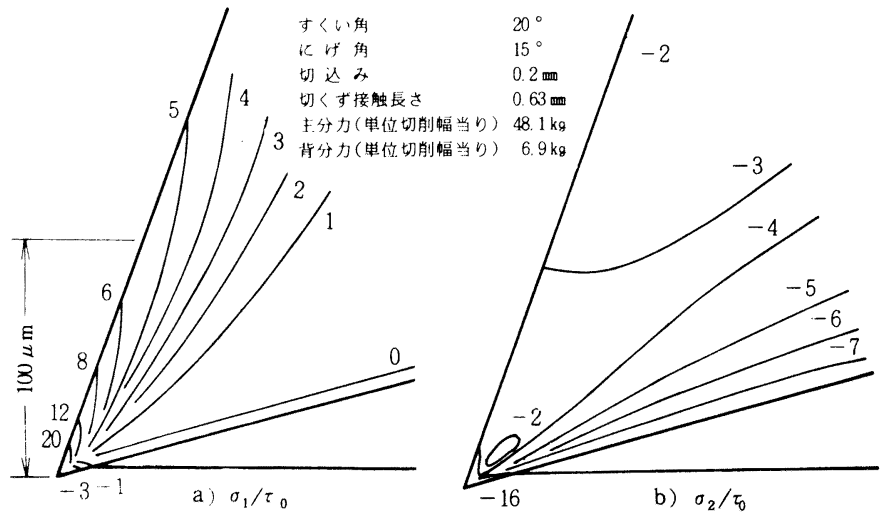

図1工具内主応力分布の 1 例 $\left(\tau_{0}:\right.$ 被削材の世九断強さ $50 \mathrm{~kg} / \mathrm{mm}$ )

表1組令世念力状態におけるワイブルパラメータ

\begin{tabular}{|c|c|c|c|c|c|}
\hline 訧力犾想 & $\begin{array}{l}\tan ^{-1} \\
\left(\sigma_{2} / \sigma_{1}\right)\end{array}$ & $m^{*}$ & $\begin{array}{l}\sigma_{u}^{*} \\
\mathrm{~kg} / \mathrm{mm} 2\end{array}$ & $\begin{array}{l}\sigma_{0}^{*} \\
\kappa g / \mathrm{mm}_{2}\end{array}$ & $\overline{\mathrm{K}_{R}^{*} / \mathrm{mm}^{2}}$ \\
\hline 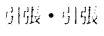 & $0 \sim 45$ & 3. 3 & 140 & 22.8 & 154 \\
\hline \multirow[t]{3}{*}{ 蚌引外 } & 0 & 3.3 & 140 & 22.8 & 154 \\
\hline & -15 & 3.7 & 134 & 28.6 & 153 \\
\hline & $30^{\circ}$ & 4. 2 & 137 & 35.6 & 163 \\
\hline \multirow[t]{3}{*}{ 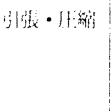 } & 40 & 4.8 & 151 & 46.1 & 187 \\
\hline & $-60^{\circ}$ & 5.5 & 183 & 63.8 & 236 \\
\hline & 75 & 6.4 & 257 & 94.1 & 339 \\
\hline \multirow[t]{2}{*}{ 㫿 軸月：維 } & $\quad-90^{\circ}$ & 9.8 & 508 & 55.1 & 561 \\
\hline & $-105^{\circ}$ & 9.8 & 594 & 56.3 & 648 \\
\hline \multirow[t]{2}{*}{ 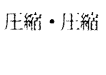 } & $-120^{\circ}$ & 9.8 & 694 & 53.4 & 745 \\
\hline & 135 & 9.8 & 745 & 50.0 & 794 \\
\hline
\end{tabular}

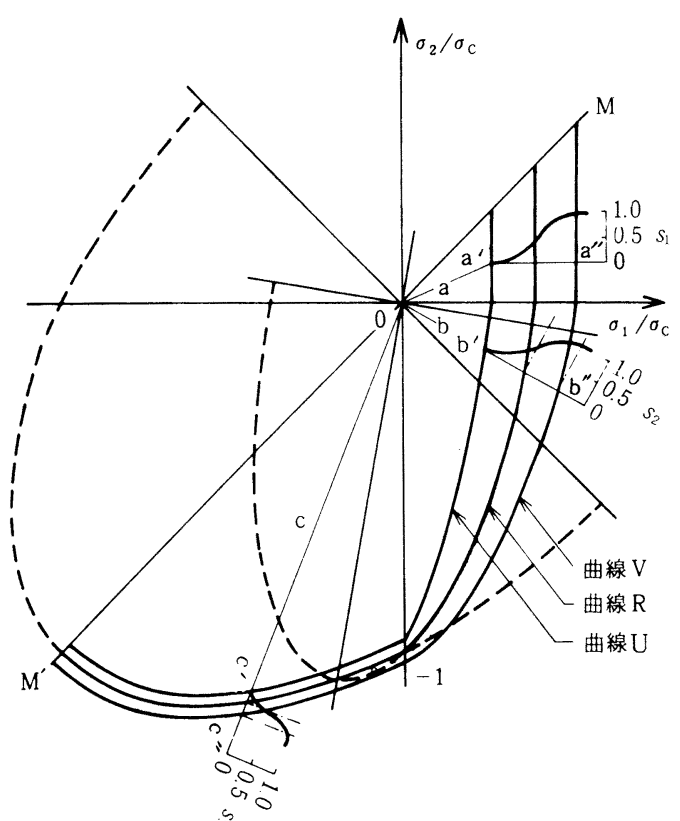

図2超硬合金の破壊についての統計的クライテリアの図的表示
として応力特性值 $\sigma^{*}=\sqrt{\sigma_{1}^{2}+\sigma_{2}^{2}}\left(\sigma_{1}, \sigma_{2}>\right.$ 0 以外吃之), $\sigma^{*}=\sigma_{1}\left(\sigma_{1}, \sigma_{2} \geqq 0 \sigma\right.$ 上 き)を考える。対采之する工具材料の破 壊発生時の破塤起点の応力特性值 $\sigma *$ は Weibull 分布にしたがうむのとし，その閜 值 $\sigma_{u}{ }^{*}$, メティアン $\sigma_{\mathrm{R}}{ }^{*}$, それに破壊確率

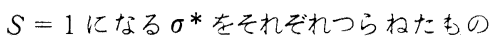
が曲線U, R, Vである(但し $\sigma_{1} / \sigma_{2}$ の大 きさは材料の単軸圧縮強度 $\sigma_{\mathrm{c}}$ により正規 化して表示してある) (付録)。曲線U上ま たは内側の応力状態にある材料の破壊確

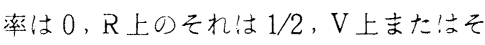
の外側のそれは 1 である。 $\mathrm{U}, \mathrm{R}, \mathrm{V}$ 性質は主応力の三種の組合女 $\left[\sigma_{1}, \sigma_{2}>\right.$ $0],\left[\sigma_{1}>0, \sigma_{2}<0\right],\left[\sigma_{1}, \sigma_{2}<0\right]$ 一によって異なる が，それぞれ単軸引張り・圧縮試騃におけるWeibullバラ メータを用いてあらわすこよができる。なお，ある一定 応力比を保った強度試験（図 2 では，O-a，O-b， $\mathrm{O}-\mathrm{C}$ 線上で $\sigma^{*}$ が変化する)を想定する上き， $\sigma^{*}$ から みた累積強度分布（ある $\sigma^{*}$ での破壊確率）が $\left[\sigma_{1}, \sigma_{2}>0\right.$ ] に対し $S_{1}\left[\sigma_{1}>0, \sigma_{2}<0\right]$ に対し $S_{2}\left[\sigma_{1}, \sigma_{2}<0\right]$ に対 し $S_{3}$ のように示される。この二軸床力下でのWeibull パ ラメータ $\sigma_{u}^{*}, \dot{\sigma}_{0}^{*}, m *$ は単軸応力下でのパラメータか ら求如付録), 表 1 亿一例呩されている。

工具内各点の応力値は, 具体的には適当な大きさ（一 辺約 $4 \mu \mathrm{m}$ または $10 \mu \mathrm{m}$ の扇形及び三角形) に分割され た微小要素にかかる平均応力上して計算され，その場合 の主応力 $\sigma_{1}, \sigma_{2}$ がわかる上，図 2 または以下に示す諸式 を用いてその要素の破壊の確率 $S_{i}$ が求まる。 $S_{i}$ はWeibull の破壊理論により次のように表わされる。

$$
\begin{aligned}
& S_{i}=1-e^{-B_{i}} \\
& B_{i}=\frac{V_{i}}{V_{0}}\left(\frac{\sigma^{*}-\sigma_{u}{ }^{*}}{\sigma_{0}^{*}}\right)^{m *}
\end{aligned}
$$

ここに, $B_{i}$ は $i$ なる微小要素の破壊の危険度, $V_{i}$ は同要 素の体積, $V_{0}^{* *}$ は物理的には破壊に関与する欠陥を 1 個 程度含む微小な一定体積, $m^{*}$ は工具材料の均一性をあら わす常数, $\sigma_{0}$ * は別の材料常数（但し $V_{0}$ に関俰する）で ある。また添字 $i$ は $i$ 番目の微小要素在示し, 分割個数 nだけある。

** 本報では $V_{0}=1 \mathrm{~mm}^{3}$ とした. Weibull 理論では、数理的 には $V_{0}$ の值は任意の大きさでよい(これに応して他の パラメー夕 $\sigma_{0}$ がきめられるので) が、大部分の取扱いで 暗黙のうちに単位体穔（たとえば $1 \mathrm{~mm}^{3}$ ) を採用している. 超硬合金の場合， $V_{n}=1 \mathrm{~mm}^{3}$ は物理的にもそれほど非 現実的ではないことが, 破战の起源に関する研究（铪木 ほか：日本金属学会誌, 38（1974），1013）などから類推 できる. 


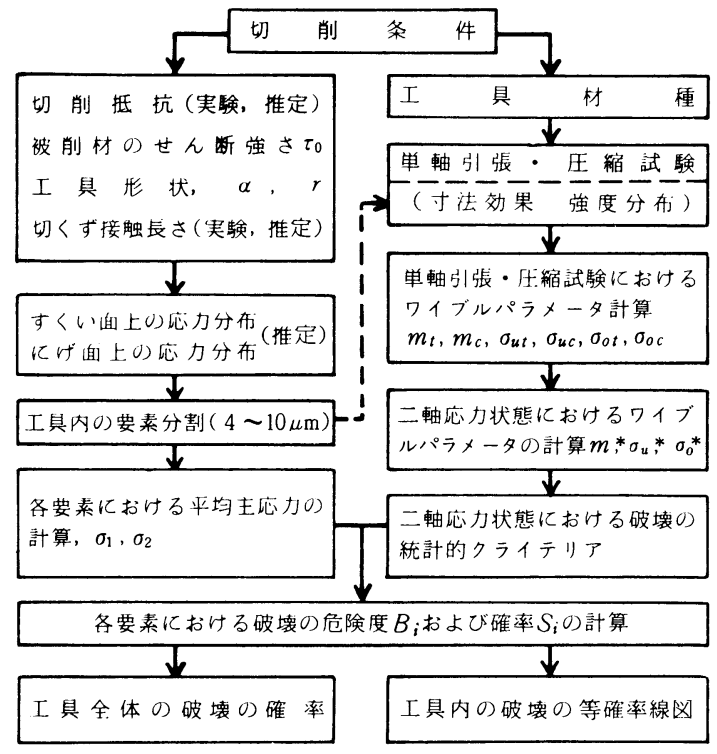

図 3 チッピングの確率的表示法の流れ

表 2 切削試験け条件

工具材質 : K 20, すくい角 $=-10^{\circ} \sim 40^{\circ}$, にげ角 $=3$ 〜 $20^{\circ}$, 被削材: SCM3 (女九断強さ $\tau_{0}=50 \mathrm{~kg} / \mathrm{mm}^{2}, \mathrm{H}_{\mathrm{V}}$ $=417$ ), 切削幅 $=3.3 \mathrm{~mm}$, 切込み $=0.1 \sim 0.35 \mathrm{~mm}$, エ ンゲージ角 $=-30^{\circ} \sim 100^{\circ}$, 切削速度 $=25 \mathrm{~mm} / \mathrm{min，}$ 切削距離 $=15 \mathrm{~mm}$, 切削液: なし

各微小要素について $S(i=1 \sim n)$ が求められるとそ れらり中で等しい確率をもつ微小要素を連衫て等確率線 甽を町く上，ある確率で，どのような範囲に破壊が起り そうであるかがわかる（以下に示す図5，9，11）。 但し，その範囲は，破壊り起点についての情報を示すす ので，最終的な破壊の形—チッピングの形——必ず しも值接示すものでない上考えるべきである。なぜなら チッピングの形をきめるのは, 破壊の起点もさるととな がら，破埢あるいはクラックの伝播経路であり，さらに それをきめるものはおそらくはクラックの進展に上もな つて再分布する応力状態であるのに，上の取扱いではそ れを考虑していないからである。

一方，工具内のどこかで破壊が発生する確率 $S_{\mathrm{T}}$ は次 式で求めるてとができる。

$$
\begin{aligned}
& S_{T}=1-e^{-B_{T}} \\
& B_{T}=\frac{1}{V_{o}} \int_{V}\left(\frac{\sigma^{*}-\sigma_{u}^{*}}{\sigma_{o}^{*}}\right)^{m *} d V
\end{aligned}
$$

そこでチッピング現象の確率的表示の手順は全体とし て図3のような流れになる。本報告では結果の表現は等 確率線図によることにする。

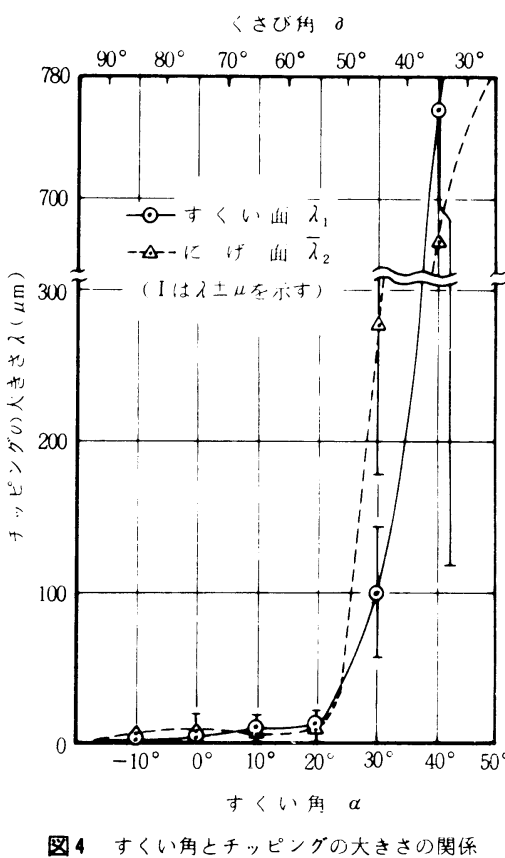

（にげ角 $r=15^{\circ}$, 㐜込み $\mathrm{t}=0.2 \mathrm{~mm}$ )

3. チッピングのモデル実験

解析の妥当性を確認する目的で表 2 に示すような条件 で二次元切削をを行なった。その結果発生するチッピング の規模は，すくい面，逃げ面の拡大写真をむ上に，工具 面上に打ける欠けの終端の刚先裂からの距離入（これを ここではチッピングの大きさよよぶこにする）であら わす。入はいうまでもなく切內の幅打何り备点で異るが $100 \mu \mathrm{m}$ 間隔で約 30 個の测定值から算術平均值 $\lambda_{1,2}$, 標準 偏差 $\mu_{1},{ }_{2}$ 在算出した。なおこの場合の添学 1 はすくい 面, 2 は逃げ面上の值を意味する。欠けの工具面からの 深さは測定しなかった。

切削実験においてチッピングが発生すると切削力に急 激な変化が生じるので, これを工具ホールダに装㯰した 加速度ピックアップからのパルス状信号によって検知し, 直ちに切削を中止して刚先の状洗を能察した：理論解析 の入力上しての切削力の値は, このパルス信号発生直前 のものを用いた。

\section{4. 切刃の形状とチッピング}

\section{1 すくい角の影霎}

図4はモデル実験におけるチッピングの大きさに対す

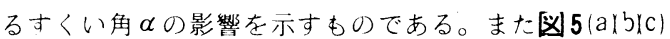
は $\alpha=0^{\circ}, 10^{\circ}$ 及び $20^{\circ}$ の工具に率中にそれぞれ示す切削 力がかかった場合の等確率線図である。この等確率線図 


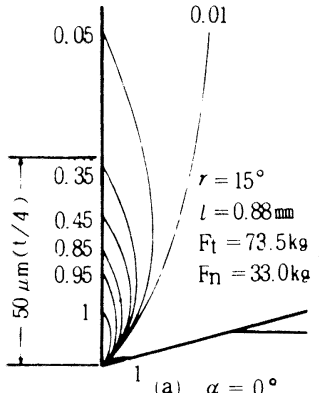

(a) $\alpha=0^{\circ}$

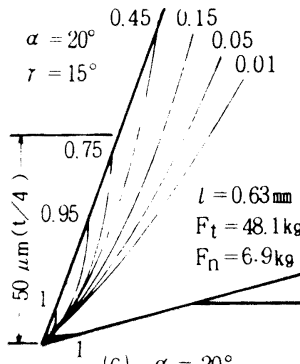

(C) $\alpha=20^{\circ}$

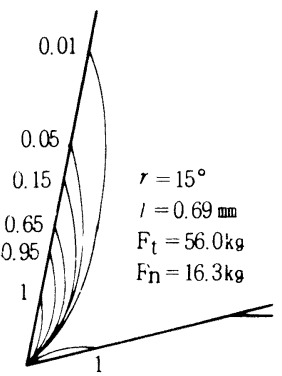

(b) $\alpha=10^{\circ}$

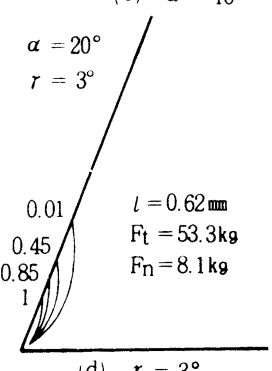

(d) $r=3^{\circ}$
図5チッピングの発生確率(等確率線図)上工具形状の 関係(切込 $\mathrm{t}=0.2 \mathrm{~mm}, \mathrm{~F}_{\mathrm{t}}$ : 単位切削幅当り主分力, $F_{n}$ : 单位切削幅当り背分力, $\ell$ : 切くず接触長さ)

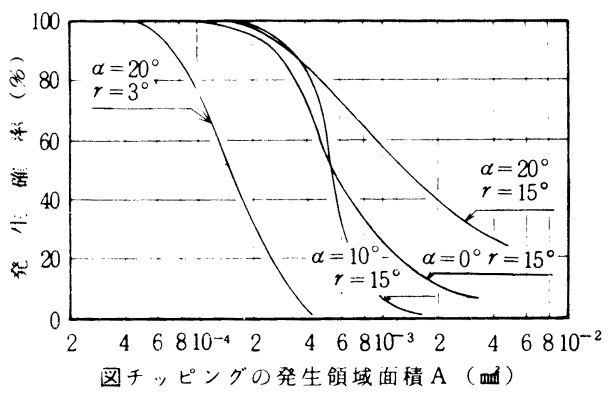

図6チッピングの発生領域之確率

とすくい面(または逃げ面)でかてまれる領域はそその確 率以上でピッチング発生の可能性のある領域（簡単のた めてれを発生領域上よふてとにする)である。さきにもふ れたように，発生領域の面積 Aは，チッピングの規模を 直接示すものではないが，両者には何等かの対応がある はず上考えてもよいであろう。そてでA上確率よの関係 をすくい角 $\alpha$ をパラメータ上して示したのが図6である。 これらを通観すると $\alpha=-10^{\circ} \sim+20^{\circ}$ の範囲では， $\alpha$ が大きくなるにつれてチッピングの大きさ亚びにある一 定の確率（とくに高い確率のレベル）をむつ発生領域の 面積Aも徐々に大きくなっており，実験と理論とがおお むねよく一致している〉ょがわかる。すくい面で観察さ れたチッピングの大きさ $\lambda_{1}$ と理論的に予測される発生 確率の大体の関係は, $\bar{\lambda}_{1}+3 \mu_{1}$ が $30 \sim 40 \%, \bar{\lambda}_{1}+\mu_{1}$

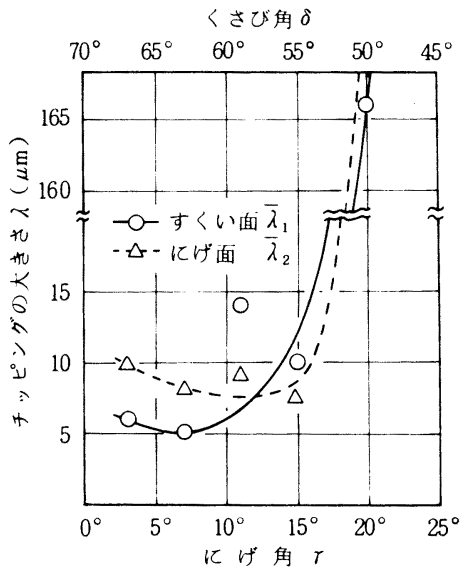

図7にげ角とチッピングの関係 (すくい角 $\alpha=20^{\circ}$ )

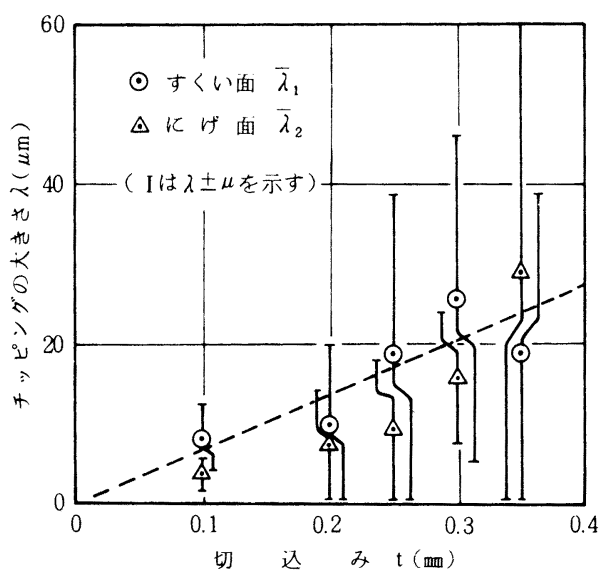

図8切込み上チッピングの関係 $\left(\alpha=20^{\circ} \gamma=15^{\circ}\right)$

がはぼ $95 \%$ ， うである。しかし逃げ面上で観察されたチッピングの大 きさ $\lambda_{2}$ 上理論的予測之はほ上んど一致しない。その理 由はおそらく，逃げ面側でのチッピングは，すくい面側 でのチッピングによって刚先強度が低下した結果発生す るためであろうと考えられる。

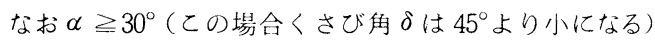
では，工具のエンゲージの際に大きな朾先欠損を生じ, またその際の切削力から刃先内部の応力分布を推定する のは不適当之思われたので解析の対象にはしなかった。

\section{2 逃げ角の影響}

図7はモデル実験におけるチッピングの大きさと逃げ 角の関係である。また逃げ角 $\gamma$ が $15^{\circ}$ 及び $3^{\circ}$ の場合（た だし $\left.\alpha=20^{\circ}\right)$ についての等確率線図が戍 $5(\mathrm{c})$ 及び(d)に示 されている。逃げ角の影響についても実験上理論は傾向 的に一致している。観察されたチッピングの大きさと理 


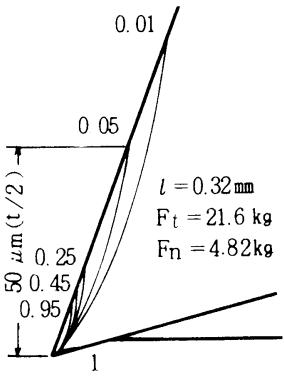

(a) $\mathrm{t}=0.1 \mathrm{~mm}$

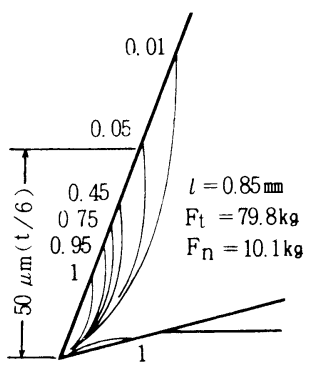

(b) $\mathrm{t}=0.3 \mathrm{~mm}$
図 9 チッビングの発生確率之切込みの関係 $\left(\alpha=20^{\circ}\right.$, $r=15^{\circ}, \mathrm{t}=0.2 \mathrm{~mm}$ については図 $5(\mathrm{c})$ 参照)

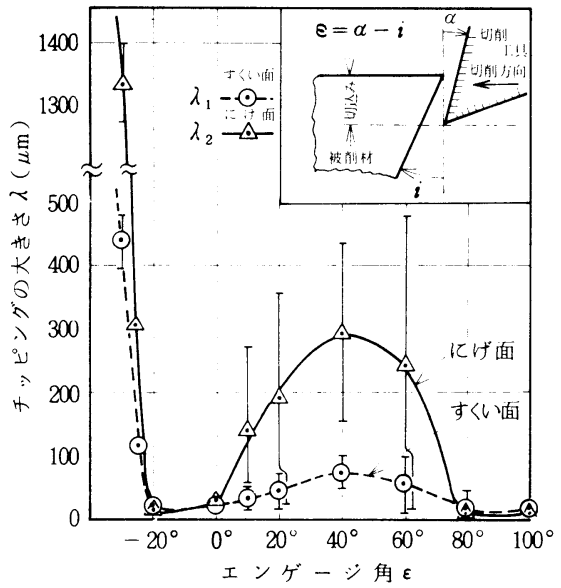

図 10 エンゲージ角とチッピングの関係 $\left(\alpha=20^{\circ}, r=15^{\circ}, t=0.2 \mathrm{~mm}\right)$

論的発生確率のおおよその関係は， $\bar{\lambda}_{1}+3 \mu_{1}$, 加確率50 〜 $60 \%$ に, $\bar{\lambda}_{1}+\mu_{1}$ が吃\%程度に， $\bar{\lambda}_{1}$ がほほ $100 \%$ に それぞれ対応しているようであり，すくい角の影響の場合 上大体似ている。

また逃げ角が大きくなり，〈さび角が $50^{\circ}$ 程度になる 之極如て大きな欠損が観察されたこ上も，すくい角が大 きくなった埸合の例よよく似ている。

\section{5. 切削条件とチッピング}

\section{1 切込の影響}

図8はモデル実験で観察されたチッピングの大きさ六 1 , $\bar{\lambda}_{2}$ 之切込 $\mathrm{t}$ の関係を示す屯ので, $\mathrm{t}$ の增加によってはぼ 単調に六が大きくなっている。モデル夷験では $\mathrm{t} \leqq 0.25$ mmではほぼ連続型の切筒排出が行なわれているが， $t \geqq$ $0.3 \mathrm{~mm}$ ではそ机が不連続型上なり切削機構に遷移がみと められた。したがって 上それ以下とでは，主分力，背分力をあとにして工具面 上の㐫力分布を推定する.上汇若干の差異を考えるべきで はあるが，ここではそれを無視して $\mathrm{t}=0.1 \sim 0.3 \mathrm{~mm}$ の埸

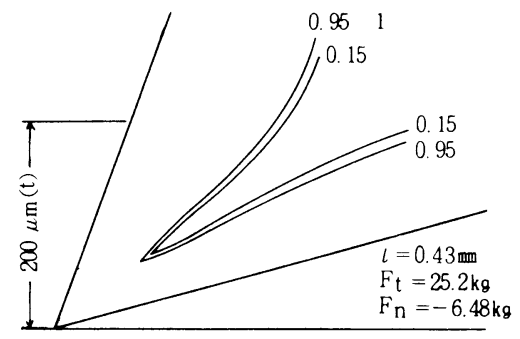

(a) $\varepsilon=-30^{\circ}$

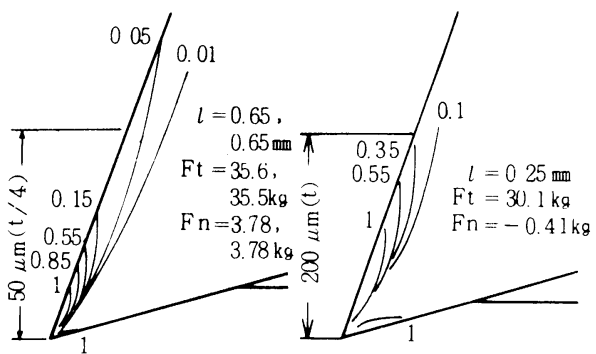

(b) $\varepsilon=0^{\circ}, 80^{\circ}$

(C) $\varepsilon=40^{\circ}$

四11エンゲーシ条件之チッピングの発生確垶 $\left(\alpha=20^{\circ}, r=15^{\circ}, \mathrm{t}=0.2 \mathrm{~mm}\right)$

について单純に求めた等確率線戍在示すよ㘡9(a)(b)及ざ 脳 $5(\mathrm{c})(\mathrm{t}=0.2 \mathrm{~mm}$ の場合) のようである。

観察されたチッピングの大きさよ理論的に予測される 発生確率の対応は, 切込による微妙な切削機構の変化の ためか工具形状の影響を解析した埸合はよ゙よくはないが， やはり傾向的には一致している。

\section{2 工具エンゲージ状態の影響}

切內チッピングに対して切削の初期状態が微妙に影響 を与えるこ上は直感的にも理解できるし，また実験的に あその重要性が指摘されてきた1118。そこで $\alpha=20^{\circ}, r=$ $15^{\circ}$ の工具によってエンゲージ解 (図 10 参照)がー $30^{\circ}$ から $100^{\circ}$ にわたるいくつかの条件で切削在行ない千ッビ ングの大きさ $\lambda$ 大 0 関係在求めた結果加図10に示され ている。 $\lambda_{1}, \lambda_{2}$ は $\varepsilon \leqq-30^{\circ}$ で㢦めて大きく，また $\varepsilon \div 40^{\circ}$ で本極大値在示すが， $\varepsilon=-20^{\circ} \sim 0^{\circ}$ 上， $\varepsilon \geqq 80^{\circ}$ では比較 的小さい。

一力それぞれの代表的な条件である $\varepsilon=-30^{\circ}, 0^{\circ}, 40^{\circ}$, $80^{\circ}$ につて，チッピングを起した時点での切削力* 在 もとにした破壊の等確摔線戍在求力る上図110ようにな り，それらの大小関係は事験上よく一致している。

\section{6. 結 論}

切削中の工县为光に打いて，小学的鿇荷ひみによって

* 各場合の工具面上の応力分布の推定一特に逃げ面の接状 態の取扱い一などは顥微鏡映画をもとにして行なった. 
発生する破推し手知在目的上する一转み在行なった。結 果老妿約する上次しようである。

1) 実験的に求引た切削力をも上にして弾性論的に推 定した工其内结力分布之，别に契験的に求如た超硬 合金ひ破㳖に閉する統計的クライテリア上在対比す るこ上により，チッピングの発生確率，あるいは或 㕣碚率で予期されるチッビングい規模がある程度定 量的に推定しうるこ上が加った。

2)上U半理䠼解析上，そ扎に対応する二次元低速切 削実験において観祭されるチッピングと老比較する 上次しこ上がいえる。

(a)すくい角，逃げ角が增すにつ机てチッピングの 大きさは大きくなるその模様はある程度予知叮能 である

(b) 切込みが增加していく埸含，切くず排出からみ た切削機構に大きな変化がなけ狄ば，チッピングの 大きさ法徐々に大きくなる。

(c) 声いい解 20 ，逃げ角 150 工具での実験によれ ダ、エンゲージ角ー30以下上 $40^{\circ}$ 近辽の塌合にチッ ビングい大きさは異常に大きくなる。この状況は半 理論的に予知叮能である。

終りに、研究の遂行にあたり御指導いただいた大防大 学・田中義信名誉教授, 牧之内三郎教授に深く感謝する

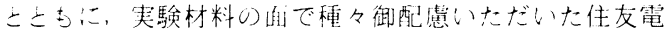

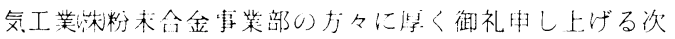

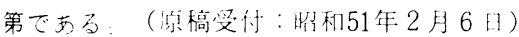

\section{付 録}

鋳鉄いような祆料に一いてFisherによって提案された 破壊し)クライテリアは只軸応力状態（上応力を $\sigma_{1}, \sigma_{2}$ かつ $\sigma_{1}>\sigma_{2}$ 上する)では次式で示される。

$\sigma_{1}, \sigma_{2}>0 \cdots \cdots, k \sigma_{1}=\sigma_{\mathrm{c}}$

$\sigma_{1}>0, \sigma_{2}<0 \cdots \cdots \cdots\left(k \sigma_{1}\right)^{2}-\left(k \sigma_{1} \sigma_{2}\right)+\sigma_{2}^{2}=\sigma_{\mathrm{c}}^{2} \quad(\mathrm{~b}$

$\sigma_{1}, \sigma_{2}<0 \cdots \cdots \cdots \sigma_{1}^{2}-\sigma_{1} \sigma_{2}+\sigma_{2}^{2}=\sigma_{\mathrm{c}}^{2}$

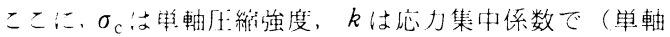

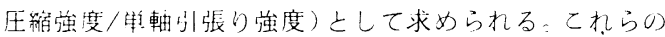

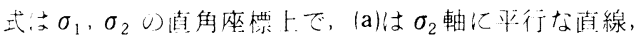

(b)去去軸在 $\tan ^{-1}\left(k / 1-k^{2}\right) / 2$ だけ，また(c)は 45 傾け た棈けひい一部でそれぞれあられされる。

一う，强度が統計的にはワイブル分们する上して，単

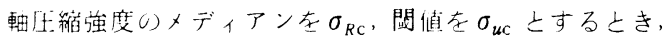
組台世就力下で破壊発生:時の伈打特性值 $\sigma^{*}=\sqrt{\sigma_{1}^{2}+\sigma_{2}^{2}}$ の分布にお计るメディアン $\sigma_{R}{ }^{*}$, 關值 $\sigma_{u}{ }^{*}$ は, 式(a), (b), (c)汇おいて $\sigma_{\mathrm{c}}$ 存 $\sigma_{R \mathrm{c}}$ または $\sigma_{u \mathrm{c}}$ にそれぞ机おきかえて得 られる関係在专って, E応力此 $\left(\sigma_{2} / \sigma_{1}\right)$ につれて変化
する上考える。前者が曲線 Rに，後者が曲線Uに相当す る。

また二軸応力下では Weibull パラメータ $m^{*}$ は次式で 示すごよく主応力比上之もに変化する上考える。

$$
\begin{array}{ll}
\sigma_{1}, \sigma_{2}>0 \cdots \cdots \cdots \cdot m *=m_{t} & \text { (a) } \\
\sigma_{1}>0, \sigma_{2}<0 \cdots \cdots \cdot m *=m_{t}+\left(m_{c}-m_{t}\right)\left(1-e^{\sigma_{2 / \sigma_{1}}}\right) & \text { (b) } \\
\sigma_{1}, \sigma_{2}<0 \cdots \cdots \cdots \cdots \cdot m *=m_{c} & \text { (c) }
\end{array}
$$

以上の手順により単軸強度試験の結果を用いて, 二軸 応力下での破壊のクライテリアを求めることができる。

更に，上のクライテリアは試料の寸法に応じて変化さ せなければならない。本研究で対象上した超硬合金 K20 の平均引張り強度がワィブル分布のメディアン $\sigma_{R t}$ に等 しい上考える上，それは四点曲归試験をもとにして実 験式(d)であらわされる。

$$
\sigma_{R t}\left(\mathrm{~kg} / \mathrm{mm}^{2}\right)=\exp (-0.0825 \ln V+\ln 154)
$$

ここにVは単軸引張り試験片の体積（min）である。

しかし關值 $\sigma_{u t}$ はほぼ一定とみなす方が適当上考えられ た。

したがって, 破壊確率を求めようとする要素の体積に よって $\sigma_{R t}$ は式(d)に示されるように変化し，そ机に上も ない他のワイブルパラメータ $\sigma_{o t}$ 屯変化するこ上になる。 但し压縮強度については寸法効果を考慮していない。な お， $\sigma_{R}, \sigma_{u}, \sigma_{0}$ の関係は次式で示される。

$$
\sigma_{R}=\sigma_{u}+\sigma_{o}\left[\frac{V_{0}}{V}(\ln 2)\right\}^{\frac{1}{m}}
$$

\section{考交献}

1) F.R.Archibald: Analysis of the Stress in a Cutting Edge, Trans. ASME, 78,6 (1956) 1149.

2) А.И. Бетанели : К исследованию прочности режүщей части инструмента, Бестник машиностроения, 2 (1964 50.

3）益田和昭：WC 系超硬切刃の圧壊強さ, 日本機械学会論 文集，35，274（1969） 1338.

4) Y. Tanaka, N. Ikawa and K. Yasugi : An Approach to Cutting Edge Chipping by Stress Analysis, Bull.Japan Soc. of Prec. Engg., 6,1 (1972) 1.

5）田中義信, 井川直哉, 安木国晴：工具刃先における応力 分布，切削工具のチッピングに関する基礎研究(第 1 報)， 精密機械，39，10（1973） 1055.

6) В.А. Остафьев : Расчет прочности режущей части инструмента, Станки и инструмент, 43, 7 (1972) 30.

7）たと之ば展望，原昭夫：超硬合金工具材料の破壊，精密 機械，39，11（1973） 1105.

8) Y. Tanaka, N. Ikawa and K. Yasugi : Proc. ICPE, Tokyo (1974) Part 1, 590.

9) J. C. Fisher: A Criterion for the Failure of Cast Iron, ASTM Bulletin, No. 181 (1952) 74 .

10) W. Weibull : A Statistical Theory of the Strength of Materials, Ing. Vetenskaps Akad. Handl. Nr 151(1939), 
A Statistical Distribution Function of Wide Applicability, J. Appl. Mech., 18 (1951) 293.

11) M. Kronenberg : Analysis of Initiat Contact of Milling Cutter and Work in Relation to Tool Life, Trans.
ASME, 68, 3 (1946) 217.

12) H.Opitz and H.Beckhaus : Influence of Initial Contact on Tool Life when Face Milling High Strength Materials, Ann. CIRP, 18, 2 (1970) 257. 